\title{
The Key Elements of the Draft Treaty Establishing Northeast Asia Nuclear-Weapon-Free Zone
}

\author{
By Kumao Kaneko (Japan)
}

\section{Basic objectives of the Treaty}

- To prevent nuclear war in Northeast Asia region by prohibiting the use or threat of use of nuclear weapons against nonnuclear-weapon States Parties to NPT;

- To promote nuclear disarmament and eventual abolition of nuclear weapons, while preventing further proliferation of nuclear weapons or technologies thereof in the region;

- To contribute, more broadly, to building confidence among the nations and maintaining peace and security within the region.

\section{Membership of the Treaty}

Four non-nuclear-weapon States: Japan

Mongolia

North Korea

South Korea

Three nuclear-weapon States:

China

Russia

US A

3. Geographical application of the Treaty

The Treaty shall apply to all the lands and territorial seas of the four non-nuclear weapon States (Japan, Mongolia, North Korea, and South Korea). The air space above the lands and territorial seas shall be included. However, nothing in this Treaty shall affect the navigational freedom of any Member States under LOS. 
The Mongolian Joumal of International Affairs

\section{Common obligations of the member States}

- All member States shall faithfully abide by their obligations under intemational law, especially those of United Nations Charter and NPT;

- They shall actively participate in intemationally concerted efforts to prevent nuclear proliferation and promote nuclear disarmament in Northeast Asia region.

- They shall consult as much as possible with other Member States for the effective implementation of basic objectives of the Treaty.

\section{Obligations of the three nuclear-weapon States}

- They shall not attack or threaten to attack any non-nuclearweapon States Parties to this Treaty and NPT with nuclear or any other weapons. (=negative security assurance)

- They shall otherwise assure as much as possible the peace and security of all the non-nuclear-weapon States

- They shall progressively dismantle or remove all their nuclear weapons within the region ( within 10 years from the date of entry-into-force of this Treaty) .

- They shall not bring nuclear weapons into the lands and territorial seas of the four NNWSs (? Except in extraordinary situation where the express consent or request is given by the States concemed.?)

- They shall accept appropriate international inspection (by IAEA?) to verify their compliance with their Treaty obligations.

- They shall not export nuclear weapons or technologies or assist the acquisition thereof by any NNWSs.

\section{Obligations of NNWSs}

- They shall reaffirm their obligations under NPT not to develop, manufacture or acquire nuclear weapons under any circumstance. 
- They shall accept IAEA safeguards (under NPT) on all nuclear activities for peaceful purposes. They shall give maximum transparency to such activities.

- They (as well as all NwSs) shall actively participate in international or regional efforts to establish multilateral nuclear fuel cycle centers/regimes under the aegis of IAEA for promoting strictly peaceful uses of nuclear energy. Nothing in this Treaty shall jeopardize such uses of muclear energy.

\section{NEA-NWFZ Treaty Agency}

All member States shall join the "NEA-NWFZ Treaty Agency" to be created for the effective implementation of the provisions of the Treaty. Such agency will be located at an appropriate place within the region. Its secretariat services being provided be member States with the help of IAEA.

\section{Cooperation with other NWFZs}

The member States shall, through the NEA-NWFZ Agency, maintain close cooperative relationship with the existing NWFZs (Tlatelolco, Rarotonga, Pelindaba, Bangkok, Semipalatinsk Treaties)

\section{Compatibility with previous treaties}

Nothing in this Treaty shall affect the rights and obligations under other international treaties which the Member States have concluded prior to the date of the entry-into-force of this Treaty. They shall, however, take all necessary measures for effective implementation of the basic objectives of this Treaty.

10. Other relevant articles

- Definitions of the terms

- Ratification accession

- Duration, review, amendments

- Settlement of disputes

\section{Important features}

- Simpler is the better for gaining political momentum and popular support.

- Mongolia with her unique experience should be invited to join as a full partner.

- Separate optional protocol (s) for NWSs will be neither desirable or necessary. They could undermine seriously the integrity of the Treaty itself. 


\title{
National legislation- an important tool for achieving the objectives of non-nuclearization: Japanese experience
}

\author{
Prof. Kumao Kaneko
}

IPPNW North Asia Regional Meeting in Ulaanbaatar, Mongolia, 21-22 June 2007

\section{History of non-nuclear Japan}

1945: Atomic bombings at Hiroshima \& Nagasaki; 1947: Pacifist Constitution prohibiting war (Art. 9) 1955: Basic Law on Peaceful Use of N-Energy 1957: Joining IAEA 1967: Three Non-Nuclear Principles (not make, not own, not allow the introduction of, $\mathrm{N}$-weapons)

1970: Signing NPT

1976: Ratifying NPT, accepting full-scope SGs 


\section{Three Non-Nuclear Principles vs. "Nuclear umbrella"}

During the Cold War period:

- Three Non-Nuclear Principles for domestic purpose

-"Nuclear umbrella" under Japan-US Security Treaty (1960) against threats from China \& USSR

Post- Cold War period:

New threats from North Korea? China?

\section{Recent changes in security environment in Northeast Asia}

- Changes in security environment in Northeast Asia (nuclear threats from North Korea, military build-up in China, etc.)

- Weakened NPT regime

- Japan-US alliance (collective self-defense, Missile Defense (MD)

- Surge in Japanese self-awareness (nationalism?) 


\section{National debates on nuclear policies: pros \& cons}

(1) Should Japan go nuclear on its own?

(2) Should continue to rely on US "nuclear umbrella"?

(3) Should explore and pursue the $3^{\text {rd }}$ path?

Three-Non-Nuclear Principles should be enshrined in "NEA-Nuclear Weapon-free Zone"

Distinguish the silent majority of people from a limited number of vocal rightist politicians

\section{Three Non-Nuclear Principles}

- Are they effective and viable?

- Should they be revised, especially No.3 principle (non-introduction into Japanese territory)?

"Kobe formula"?

- Should they be kept intact?

- Should they be strengthened by making them into domestic law ?

- How to harmonize security needs and nonnuclear position? In NEA-NWFZ Treaty? 


\section{Strengthening Three Non- Nuclear Principles}

No. 1 and No.2 principles should be restated in the New Constitution (when it is revised) as well as in the NEA-NWFZ Treaty

How to deal with No.3 principle?

(introduction=passage in territorial seas)

- Adopt the present Japan-US formula?

- How to accommodate it in NEA-NWFZ

Treaty? Rarotonga, Bangkok model?

\section{Conclusions}

- To narrow as much as possible the gap between ideals and realities

(Idealistic realism, realistic idealism)

- Step by step approach

- Get people and politicians involved

- For the moment, make good use of the

- 2010 NPT Review Conference 